\title{
DINAMIKA KELOMPOK DAN TINGKAT ADOPSI PENGELOLAAN TANAMAN TERPADU (PTT) PADI PADA KELOMPOK TANI DI DESA ARJASA KECAMATAN ARJASA KABUPATEN JEMBER
}

\author{
Anik Susilowati, Lenny Widjayanthi, Djoko Soejono \\ Program Studi Agribisnis, Fakultas Pertanian, Universitas Jember \\ Jln. Kalimantan 37, Jember 68121 \\ E-mail : anick_as@yahoo.co.id
}

\begin{abstract}
Food crops, especially rice, are the main crops cultivated by most Indonesian farmers. One of the strategies taken by the government to increase rice production in Indonesia is through Integrated Crop Management Field School (ICMFS) program. The success of the development program can be seen from the approach within the group. Farmer groups have a strategic position in realizing the application of integrated cultivation, therefore every farmer has different adoption level in applying ICM. The purpose of this study is to: (1) the dynamics of groups in farmer groups in Arjasa, (2) the adoption of Integrated Crop Management of rice at farmer group at in Arjasa, (3) the relationship between socio-economic factors with the adoption ICM of rice in Arjasa. Determination of research area using Purposive Method. The method used in this research is descriptive and correlation. Sampling method using Purposive Sampling and Proporsinate Random Sampling. Methods of data collection using structured interviews, observation, document. Analyzer used is Likert scale and Rank Spearman correlation. The results showed: (1) the dynamics of farmer groups in Arjasa as a whole is dynamic. (2) the adoption of Integrated Crop Management (ICM) of rice in the farmer group in Arjasa as a whole is high (3) there is a significant correlation between age factor and experience with ICM adoption. While the factors of education, land area, income, and information sources do not have a significant relationship with the adoption of ICM.
\end{abstract}

Keywords: Group Dynamics, Adoption, Integrated Crop Management (ICM)

\section{PENDAHULUAN}

Pertanian di Indonesia tetap dianggap terpenting dari keseluruhan pembangunan ekonomi, apalagi semenjak sektor pertanian ini menjadi penyemangat perekonomian nasional karena justru pertumbuhannya meningkat, sementara sektor lain pertumbuhannya negatif. Beberapa alasan yang mendasari pentingnya pertanian di Indonesia: (1) potensi sumberdaya yang besar dan beragam, (2) pangsa terhadap pendapatan nasional cukup besar, (3) besarnya penduduk yang menggantungkan hidupnya pada sektor pertanian, dan (4) menjadi basis pertumbuhan di pedesaan. Pembangunan pertanian pada era reformasi mengalami perubahan paradigma dari paradigma lama yang yang berorientasi kepada upaya-upaya peningkatan produksi pertanian, kepada paradigma baru yang lebih berorientasi kepada peningkatan pendapatan dengan menerapkan sistem agribisnis. (Suprapto, 2010).
Program Sekolah Lapang Pengelolaan Tanaman Terpadu (SLPTT) berawal dari gagasan Pengendalian Hama Terpadu (PHT) serta partisipasi pada tahun 1989. Selanjutnya menjadi Pengelolaan Tanaman Terpadu (PTT) yang menerapkan berbagai teknologi usahatani melalui input produksi yang efisien menurut spesifik lokasi, sehingga mampu menghasilkan produktivitas tinggi untuk menunjang peningkatan produksi yang berkelanjutan. Melalui penerapan SLPTT petani akan mampu mengelola sumberdaya yang berkelanjutan. Melalui penerapan SLPTT petani akan mampu mengelola sumberdaya yang tersedia secara terpadu dalam melakukan budidaya dalam usahataninya dan lebih terampil serta mampu mengembangkan usahataninya (Dirjen Tanaman Pangan, 2012).

Program-program pemerintah dalam peningkatan produksi yang berupa bantuan untuk petani sering diikuti dalam kegiatan SLPTT 
dan diharapakan dengan penyertaan program tersebut dalam program peningkatan produksi pangan dapat mencapai sasaran yang tepat seperti yang dikehendaki. Berdasarkan survey, kondisi yang dialami dalam pelaksanaan SLPTT di Desa Arjasa Kecamatan Arjasa Kabupaten Jember adalah masih adanya petani yang belum menggunakan bibit unggul bermutu, penggunaan bibit tua, cara tanam masih belum sesuai karena budidaya tanaman padi masih belum sepenuhnya dimengerti oleh para petani, petani masih enggan menggunakan pupuk organik, langkanya pupuk anorganik/ pupuk bersubsidi, waktu pemupukan kurang tepat, masih banyak petani yang melakukan tanam tabur langsung, masih banyak petani yang menggunakan teknik menanam tidak secara larikan (rapi), terasa jauh dari apa yang ada dalam prinsip-prinsip PTT, untuk itu diperlukan penelitian yang mendalam mengenai kedinamisan kelompok tani dan tingkat adopsi Pengelolan Tanaman Terpadu (PTT) dalam kegiatan Sekolah Lapang Pengelolaan Tanaman Terpadu (SLPTT) padi di Desa Arjasa Kecamatan Arjasa Kabupaten Jember serta menganalisis tentang hubungan antara faktor sosial ekonomi dengan adopsi PTT.

Adapun tujuan dari penelitian ini adalah (1) Untuk mengetahui dinamika kelompok pada kelompok tani di Desa Arjasa Kecamatan Arjasa Kabupaten Jember; (2) Untuk mengetahui tingkat adopsi Pengelolan Tanaman Terpadu (PTT) padi dalam program SLPTT di Desa Arjasa Kecamatan Arjasa Kabupaten Jember; (3) Untuk mengetahui hubungan antara faktor-faktor sosial ekonomi dengan adopsi Pengelolaan Tanaman Terpadu (PTT) padi di Desa Arjasa Kecamatan Arjasa Kabupaten Jember.

\section{METODE PENELITIAN}

Daerah penelitian ditentukan secara sengaja (Purposive Method) yaitu di Desa Arjasa Kecamatan Arjasa Kabupaten Jember. Metode penelitian yang digunakan yaitu metode deskriptif dan korelasi. Sampel dalam penelitian dilakukan secara Purposive Sampling dan Proporsionate Random Sampling yaitu 40 petani yang mengikuti program SLPTT di Desa Arjasa Kecamatan Arjasa Kabupaten Jember. Metode pengumpulan data yang digunakan adalah metode wawancara terstruktur, observasi dan dokumen.

Untuk menguji hipotesis pertama dan kedua dapat dianalisis secara deskriptif dan kualitatif dengan menggunakan skor sebagai kriteria pengambilan keputusan. Setiap indikator dari sub-sub variabel di atas diberi rentang nilai antara 1-3 dengan kategori nilai dibagi menjadi 1 (rendah), 2 (sedang), dan 3 (tinggi). Sehingga kriteria pengambilan keputusan hipotesis pertama yaitu:

a. Dinamika kelompok tani tidak dinamis (skor 56-93)

b. Dinamika kelompok tani cukup dinamis (skor 94 - 130)

c. Dinamika kelompok tani dinamis (skor 131 -167)

Sedangkan kriteria pengambilan keputusan hipotesis kedua yaitu:

a. Tingkat adopsi PTT rendah (skor $33-55$ )

b. Tingkat adopsi PTT sedang (skor 56-77)

c. Tingkat adopsi PTT tinggi (skor 78 - 99)

Untuk menguji hipotesis ketiga mengenai digunakan analisis korelasi Rank Spearman. Dengan formulasi sebagai berikut (Hasan, 2011):

$$
\mathrm{r}_{\mathrm{s}}=1-\frac{6 \sum \mathrm{d}^{2}}{\mathrm{n}(\mathrm{n} 2-1)}
$$

Dimana : $r_{s}$ : Koefisien korelasi rank spearman $\mathrm{d}$ : Selisih dalam ranking

$\mathrm{n}$ : Banyaknya pasangan rank

Hipotesis dan kriteria pengambilan keputusan yang digunakan adalah :

$\mathrm{H}_{0}: \mathrm{r}_{\mathrm{s}}=0$, artinya tidak terdapat hubungan yang signifikan antara umur, pendidikan, pengalaman, pendapatan, luas lahan dan sumber informasi yang diperoleh dengan adopsi PTT pada kelompok tani di Desa Arjasa Kecamatan Arjasa Kabupaten Jember.

$\mathrm{H}_{1}: \mathrm{r}_{\mathrm{s}} \neq 0$, artinya terdapat hubungan yang signifikan antara umur, pendidikan, pengalaman, pendapatan, luas lahan dan sumber informasi yang diperoleh dengan adopsi PTT pada kelompok tani di Desa Arjasa Kecamatan Arjasa Kabupaten Jember.

Kriteria pengambilan keputusan :

Nilai signifikansi $<0,05$ maka $\mathrm{H}_{0}$ ditolak dan $\mathrm{H}_{1}$ diterima, terdapat hubungan yang signifikan antara umur, pendidikan, pengalaman, pendapatan, luas lahan dan sumber informasi yang diperoleh dengan adopsi PTT pada kelompok tani di Desa Arjasa Kecamatan Arjasa.

Nilai signifikansi $>0,05$ maka $\mathrm{H}_{0}$ diterima dan $\mathrm{H}_{1}$ ditolak, tidak terdapat hubungan 
yang signifikan antara umur, pendidikan, pengalaman, pendapatan, luas lahan dan sumber informasi yang diperoleh dengan adopsi PTT pada kelompok tani di Desa Arjasa Kecamatan Arjasa.

\section{HASIL DAN PEMBAHASAN \\ Dinamika Kelompok pada Kelompok Tani di Desa Arjasa Kecamatan Arjasa Kabupaten Jember}

Berdasarkan hasil analsis dapat disimpulkan bahwa dinamika kelompok pada kelompok tani secara keseluruhan termasuk dalam kategori dinamis. Hal ini tidak terlepas dari peran anggota kelompok maupun peran kerja dari PPL. Hubungan yang harmonis, seringnya interaksi dan komunikasi yang lancar antar anggota, pengurus, maupun PPL yang dapat menjadikan dorongan anggota untuk berani menuangkan ide tentang berbagai hal, baik dalam usahatani maupun hal lain yang menyangkut kegiatan usahatani. Komunikasi dan interaksi antar PPL dengan para anggota kelompok tani tidak hanya terbatas dalam pertemuan kelompok, melainkan dapat terjadi kapan saja ketika para petani membutuhkan berbagai informasi dan penyelesaian masalah pertanian yang petani hadapi.

Dinamika kelompok pada kelompok tani di Desa Arjasa Kecamatan Arjasa Kabupaten Jember dapat dilihat dari berbagai indikator yang diantaranya: tujuan kelompok, struktur organisasi kelompok, fungsi tugas kelompok, pemeliharaan dan pengembangan kelompok, kesatuan kelompok, suasana kelompok, tekanan kelompok, efektivitas kelompok dan maksud terselubung (Ibrahim, 2002).

\section{Tujuan Kelompok}

Hasil penelitian menunjukkan bahwa tujuan kelompok ditentukan dengan jalan musyawarah antar anggota. Tujuan utama petani padi menjadi anggota kelompok tani dilihat dari hasil penelitian menunjukkan bahwa sebesar 66,67 \% responen menjawab karena untuk mendapatkan bantuan modal budidaya, menambah pengetahuan, dan meningkatkan hasil panen. Sebesar $72,50 \%$ petani responden keinginanya dapat tercapai setelah bergabung dalam kelompok tani dan sisanya masih belum. Petani responden masih merasa belum merasa puas terhadap hasil kegiatan program yang telah dilakukan oleh kelompok karena keterbatasan waktu yang diberikan pada anggota kelompok dalam setiap kegiatan, meskipun kegiatannya sudah berjalan dengan baik.

\section{Struktur Kelompok}

Struktur kelompok dalam kelompok tani di desa Arjasa Kecamatan Arjasa Kabupaten Jember sudah terbentuk berdasarkan kesepakatan musyawarah, terbuka dan sesuai dengan keinginan anggota. Hal ini dilakukan dengan tujuan agar tidak ada kesenjangan antar anggota yang memiliki pendapat berbeda dalam menentukan pengurus. Struktur organisasi tersebut terdiri dari ketua, sekretaris, bendahara dan anggota kelompok.

\section{Fungsi Tugas}

Hasil penelitian menunjukkan bahwa sebesar $47,50 \%$ petani responden menyatakan bahwa tugas kelompok adalah menginformasikan teknologi baru kepada anggotanya dan sebesar $52,50 \%$ petani responden menganggap tugas kelompok adalah membantu kegiatan usahatani dan pasca panen anggotanya. Kegiatan usahatani yang dilakukan secara bersama-sama berdasarkan pengarahan penyuluh, seperti pelaksanaan usahatani yang dilakukan secara bersama oleh anggota dan pengendalian hama penyakit yang menyerang tanaman.

\section{Pemeliharaan dan Pengembangan Kelompok}

Hasil penelitian menunjukkan bahwa pembinaan berasal dari penyuluh yang dilakukan melalui kegiatan penyuluhan dalam pertemuan rutin dalam bentuk pemberian materi dan praktek langsung di lahan pertanian. Sebesar $92,50 \%$ petani responden menyatakan bahwa kelompok mendapatkan dukungan dari tokoh masyarakat, seperti tokoh agama, aparat desa, dll. Petani anggota menyatakan selalu diajak oleh pengurus untuk meningkatkan keikutsertaan dan partisispasi dalam kegiatan yang dilakukan oleh kelompok.

\section{Kekompakan Kelompok}

Sebesar 22,50\% petani responden menyatakan bahwa pernah melakukan kerjasama dalam pemenuhan modal dan sarana produksi dan sisanya tidak pernah. Sebesar $60 \%$ petani responden pernah melakukan kerjasama dibidang pemasaran hal ini dilakukan karena tidak ada koperasi yang membantu kegiatan kelompok. 


\section{Suasana Kelompok}

Suasana yang diinginkan dalam kelompok tani di Desa Arjasa adalah dapat saling bertukar informasi dan berkomunikasi secara lancar baik dengan antar sesama anggota maupun dengan penyuluh sehingga dapat menumbuhkan perasaan bersemangat dan persaudaraan yang sangat erat satu sama lain dan dapat dengan bebas menyampaikan pendapatnya. Dengan adanya perasaan rasa persaudaan yang tinggi dan menyenangkan maka segala aktifitas yang dilakukan dapat berjalan dengan baik dan menyenangkan.

\section{Tekanan Kelompok}

Bentuk tekanan kelompok ada dua yaitu tekanan yang berasal dari dalam kelompok misalnya adanya persaingan dan konflik antar anggota, sedangkan tekanan dari luar kelompok misalnya kekhawatiran merosotnya harga jual gabah. Norma yang ada dalam kelompok tani di Desa Arjasa adalah saling menghargai satu sama lain, bertanggung jawab atas hak dan kewajiban anggota kelompok.

\section{Efektifitas Kelompok}

Kelompok dikatakan efektif jika behasil mencapai tujuannya. Mayoritas petani menyatakan puas atas rencana kerja kelompok, karena petani pada akhirnya mampu menyerap informasi yang disampaikan penyuluh sehingga menambah pengetahuan dan ketrampilan dalam berusahatani. Sekolah lapang yang telah dilaksanakan dan didampingi oleh penyuluh dapat memberikan contoh nyata bagi anggota. Harapan program tersebut adalah dapat memperlancar usaha petani.

\section{Maksud Terselubung}

Mayoritas petani responden menyatakan bahwa setelah begabung menjadi anggota kelompok adalah berkeinginan untuk menambah pengetahuan dan meningkatkan hasil panen mereka. Peningkatan pengetahuan merupakan hal yang penting, mengingat semakin intensifnya kerjasama serta semakin tingginya pengetahuan petani maka akan menumbuhkan inovasi, daya kreasi serta kemandirian dalam kelompok. Terpenuhinya maksud terselubung anggota akan mendorong semakin aktifnya anggota kelompok dalam melaksanakan tugas dan kegiatan kelompok yang akan meningkatkan kedinamisan suatu kelompok

\section{Tingkat Adopsi Pengelolaan Tanaman Terpadu (PTT) Padi pada Kelompok Tani di Desa Arjasa Kecamatan Arjasa Kabupaten Jember}

Berdasarkan hasil analisis menunjukkan bahwa tingkat adopsi Pengelolaan Tanaman Terpadu padi dalam pelaksanaan kegiatan program SLPTT di Desa Arjasa Kecamatan Arjasa Kabupaten Jember termasuk dalam kategori tinggi. Hal tersebut terlihat dari jumlah keseluruhan petani yang mengikuti kegiatan SLPTT sebanyak 40 petani responden mampu menerapkan komponen yang ada dalam buku petunjuk PTT. Hal ini dapat dijelaskan bahwa hampir semua kegiatan SLPTT yang di pandu oleh penyuluh dapat dilakukan oleh petani. Berbagai upaya telah dilakukan oleh petani untuk bisa memperbaiki hasil panen padinya. Salah satu cara yang dilakukan oleh petani yaitu dengan mengikuti kegiatan SLPTT. Tingkat adopsi PTT pada kelompok tani di Desa Arjasa Kecamatan Arjasa Kabupaten Jember dapat dilihat dari komponen-komponen PTT sebagai berikut:

\section{Pemilihan Varietas dan Kebutuhan Benih}

Varietas padi yang di gunakan dalam penelitian ini adalah padi inhibrida yaitu situbagendit dengan umur tanam sekitar 105 hari. Setiap luasan 1 hektar area penanaman, biasanya petani membutuhkan benih sekitar $40-45 \mathrm{~kg}$. Pemilihan varietas tanaman padi berdasarkan pada usia tanam, ketahanan hama penyakit dan varietas yang sesuai dengan musim, serta penggunaan benih bersertifikat.

\section{Persemaian dan Penyiapan Bibit}

Persemaian dilakukan secara berkelompok, hal ini dilakukan oleh petani untuk mendapatakan bibit berkualitas baik dan memudahkan petani dalam perawatan bibit. Penyiapan bibit dilakukan dengan cara perendaman benih selama $24 \mathrm{jam}$. Pemindahan bibit padi inhibrida baik dilakukan pada usia tanam muda yaitu pada usia 18-21 hari. Tujuan pemindahan bibit pada umur muda sangat dianjurkan karena akan menghasilkan anakan yang banyak di lahan persawahan

\section{Pengelolaan Lahan}

Pengolahan tanah yang dilakukan oleh petani berdasarkan pada penggunaan pupuk organik sebelum proses pengolahan tanah, 
pengolahan lahan setelah panen, penggunaan hand traktor dan proses penggenangan air pada area persawahan. Pengolahan tanah dilakukan setelah proses pemanenenan, dimana setelah panen petani dianjurkan untuk segera melakukan pengolahan tanah sebagai upaya untuk mencegah adanya serangan hama penyakit.

\section{Pengairan}

Pengairan yang dilakukan oleh petani berdasarkan pada pengairan secara berselang dalam keadaan macak-macak selama masa tanam, pada umur 0-15 hari dan baru melakukan pengairan lagi pada umur 25-40 hari. Keuntungan dari pengairan berselang adalah dapat menghemat air irigasi dan baik untuk hasil panen karena gabah bisa masak secara bersamaan. Selain itu petani merasa lebih mudah dalam hal pengendalian hama dan gulma yang berada disekitar sawah.

\section{Cara Tanam}

Seluruh petani melakukan penanaman secara serempak dengan maksud agar tanaman padi terhindar dari serangan hama yang dapat merusak hasil panen. Penanaman serempak tidak harus bersamaan waktunya dalam melakukan penanaman, jarak tanam maksimal 2 minggu. Bibit yang telah disebar dibedengan persemaian selama 10-20 hari akan langsung dipindahkan kelahan yang siap untuk diatanami. Sistem tanam yang dilakukan adalah sistem tanam jajar legowo. Jarak untuk menanam dengan sistem tanam jajar legowo adalah $40 \mathrm{~cm}$ x $20 \mathrm{~cm} \times 10 \mathrm{~cm}$ dan jumlah tanaman yang dibutuhkan yaitu 2-3 rumpun/lubang.

\section{Pemupukan Berimbang}

Pemupukan awal bersamaan dengan pengolahan tanah, penggunaan pupuk organik untuk proses pemupukan dasar, pengolahan sisa jerami sebagai bahan organik, pemupukan secara tepat waktu dan berimbang serta penggunaan dosis pupuk yang sesuai dengan kebutuhan tanam. Pemupukan dilakukan pada 15-30 HST dan 30-40 HST hingga panen. Adapun dosis pupuk yang digunakan oleh petani yang sesuai dengan buku PTT adalah menggunakan perbandingan 5:3:2 yang terdiri dari urea, NPK, dan organik

\section{Penyiangan}

Penyiangan yang dilakukan oleh petani dilakukan rutin dan tepat waktu, melakukan penyiangan sedini mungkin dan sesuai dengan populasi gulma. Adapun jenis gulma yang tumbuh diarea sawah yaitu enceng padi, tekitekian, dan tangkatang. Penyiangan yang dilakukan secara rutin dan sedini mungkin sangat baik untuk pertumbuhan tanaman padi, karena padi akan mudah tumbuh tanpa adanya tanaman pengganggu. Petani rata-rata melakukan penyiangan secara manual karena dianggap lebih mudah dan gulma tercabut hingga keakar

\section{Pengendalian OPT}

Mayoritas petani telah melakukan pemotongan jerami sesegera mungkin serta membakarnya setelah panen, hal ini dilakukan agar mencegah adanya serangan hama penyakit. Petani menyatakan bahwa kemungkinan tanaman terserang hama penyakit sangat kecil jika petani melakukan pengendalian sedini mungkin. Jika nampak tanda-tanda penyakit menyerang tanaman padi, maka hal yang dilakukan oleh petani yaitu melakukan penyemprotan dengan dosis yang sesuai dengan kebutuhan tanaman. Adapun hama yang dikeluhkan petani setempat adalah wereng coklat dan burung. Penyakit yang sering menyerang tanaman padi petani biasanya adalah tungro, xantomonas, penggerek batang, dan wereng coklat.

\section{Pemanenan}

Proses pemanenan yang dilakukan dilakukan secara berkelompok, tepat waktu, dan pada kondisi lahan sawah kering. Sebagian besar petani responden melakukan pemanenan secara berkelompok pada saat umur padi sudah mencapai 105 HST (85\% bulir sudah menguning dan keras), hal tersebut dilakukan agar menghemat waktu yang digunakan. Pemanenan dilakukan sesegera mungkin, karena masa panen sangat berpengaruh terhadap jumlah, mutu gabah, dan beras.

\section{Faktor Sosial Ekonomi Yang Berhubungan Dengan Adopsi Pengelolaan Tanmaan Terpadu (PTT) Padi pada Kelompok Tani di Desa Arjasa Kecamatan Arjasa Kabupaten Jember}

Menurut Hartanto (dalam Sutarto, 2008), karakteristik sosial ekonomi petani meliputi: umur, pendidikan, pengalaman, luas lahan, pendapatan dan sumber informasi. sehingga hasil analisis Rank Spearman (rs) terhadap faktor sosial ekonomi dengan adopsi PTT padi dapat dilihat pada tabel 1 : 
Tabel 1. Hasil Analisis Korelasi Rank Spearman Mengenai Faktor Sosial Ekonomi yang Berhubungan dengan Adopsi PTT Padi pada Kelompok Tani di desa Arjasa Kecamatan Arjasa Kabupaten Jember

\begin{tabular}{clcr}
\hline No. & Faktor Sosial Ekonomi & Koefisien Rank Spearman & Signifikansi \\
\hline 1 & Umur & $0,481^{* *}$ & 0,003 \\
2 & Pendidikan & 0,087 & 0,073 \\
3 & Pengalaman & $0,413^{* *}$ & 0,008 \\
4 & Luas Lahan & $-0,089$ & 0,586 \\
5 & Pendapatan & $-0,087$ & 0,593 \\
6 & Sumber Iformasi & $-0,190$ & 0,241 \\
\hline
\end{tabular}

Sumber: Data Primer Diolah Tahun 2016

Berdasarkan hasil uji korelasi Rank Spearman (rs) antara faktor sosial ekonomi dengan adopsi Pengelolaan Tanmaan Terpadu (PTT) padi pada kelompok tani di Desa Arjasa Kecamatan Arjasa Kabupaten Jember diketahui bahwa terdapat hubungan yang signifikan antara faktor umur dan faktor pengalaman dengan adopsi Pengelolaan Tanaman Terpadu padi di Desa Arjasa Kecamatan Arjasa Kabupaten Jember. Hal ini berdasarkan hasil perhitungan uji Rank Spearman diperoleh nilai signifikansi lebih kecil dari taraf kepercayaan sebesar 95\%, hal ini dikarenakan mayoritas umur responden yang tergabung dalam kelompok tani di Desa Arjasa merupakan petani yang masih tergolong produktif dan memiliki pengalaman yang cukup lama dalam berusahatani sehingga faktror tersebut menjadikan modal dasar bagi petani dalam menerapkan inovasi yang diberikan oleh penyuluh. Sedangkan faktor pendidikan, luas lahan, pendapatan, dan sumber informasi tidak memiliki hubungan yang signifikan dengan adopsi Pengelolaan Tanaman Terpadu. Hal ini dikarenakan faktor-faktor tersebut tidak mempengaruhi keputusan petani dalam menerapkan komponen yang sudah dianjurkan penyuluh, dengan kata lain setiap individu dari petani baik yang memiliki pendidikan tinggi atau rendah, memiliki lahan luas atau sempit, berpendapatan besar atau kecil, dan memiliki sumber informasi yang banyak atau sedikit tetap memiliki kesempatan yang sama dalam mengikuti program Pengelolaan Tanaman Terpadu.

\section{KESIMPULAN DAN REKOMENDASI}

Dinamika kelompok tani di Desa Arjasa Kecamatan Arjasa Kabupaten Jember secara keseluruhan adalah dinamis.
Tingkat adopsi Pengelolaan Tanaman Terpadu (PTT) padi pada kelompok tani di Desa Arjasa Kecamatan Arjasa Kabupaten Jember secara keseluruhan adalah tinggi.

Terdapat hubungan yang signifikan antara faktor umur dan pengalaman dengan adopsi PTT padi, sedangkan faktor pendidikan, luas lahan, pendapatan dan sumber informasi tidak memiliki hubungan yang signifikan dengan adopsi PTT.

.Kelompok tani diharapkan lebih aktif lagi dalam usaha pengembangan kelompok taninya serta meningkatkan kualitas SDM agar semakin berkembang.

Petani hendaknya dapat menerapkan komponen PTT secara keseluruhan guna meningkatkan produktivitas padi dan juga masih diperlukan pembinaan yang lebih intensif untuk periode waktu yang akan datang.

Sebaiknya petani yang berpendapatan rendah dapat meningkatkan pendapatannya dari bidang non pertanian sehingga dapat digunakan untuk mendapatkan tambahan modal dan memperluas usahataninya.

\section{DAFTAR PUSTAKA}

Derektorat Jendral Tanaman Pangan. 2012. Pedoman Teknis Sekolah Lapang Pengelolaan Tanaman Terpadu (SLPTT) Padi. Jakarta

Hasan, Iqbal. 2011. Pokok-Pokok Materi Statistik 2 (Statistik Inferensi). Jakarta: PT Bumi Aksara

Ibrahim, Jabal Tarik. 2002. Sosiologi Pedesaan. Malang: UMM Press.

Suprapto, Edy. 2010. Analisis Faktor-Faktor Yang Mempengaruhi Usahatani Padi Organik Di Kabupaten Sragen. Tesis. 
Surakarta: Agribisnis Fakultas Pertanian Ekonomi

Sutarto. 2008. Hubungan sosial ekonomi petani dengan tingkat adopsi teknologi komoditas jagung di Sukoharjo Wonogiri. Jurnal Agritexts No.24 